of grass-drying machinery and equipment is given, and comparison mado with tho various processes of artificial drying in other countries. Thero seems to bo littlo doubt that the conservation of young grass is sound in principlo, as it is then at its maximum nutritive value, and feeding trials show that it can largely replace concentrates. The question of the profitableness of grass-drying, however, cannot bo answered so simply, as it depends.both on the quality of the product and also on other matters such as the market value of the concentrates which it is to substitute, and whether the grass would have been utilized in somo other manner or wasted through occurring at a time of surplus growth. Tho indirect advantages of the process, such as improvement of tho sward, control of thistle, etc., must not bo overlooked, nor the fuct that the lower grades of dried grass are of higher value than tho best hay. Profitmaking, howover, in this as in many farming enterprises, depends to a very largo extent on tho skill of the individual.

\section{Agricultural Libraries}

THe Internationnl Institute of Agriculture in Romo has just published a useful book of reference entitled "International Directory of Agricultural Librarics" (25 lira). Tho information consists of a list of all general agricultural libraries of moro than two thousand volumes, libraries specialized in particular subjects, agricultural collections in general libraries, and centres of agricultural documentation. So far as possible, the history and size of the library and tho subjects represented therein, the cataloguing and classification systems employed and regulations for the use of the library aro stated. Relations with other libraries (exchange of publications, etc.), a bibliography of writings on tho library and any publications cdited by it aro also mentioned. 1,200 libraries arranged according to country aro described, and the text is written in both English and French.

\section{Theodor Langhans (1839-1915)}

Tryodor IaAvghans, an eminent German pathologist, who with tho physician Sahli and tho surgeon Kocher formed a triumvirato which mado tho Berno medical school famous, was born at Usingen, N'nssau, on September 28, 1839. Ho received his medical education at Heidelberg; Göttingen, where ho was a pupil of the celcbrated anatornist Henlo; Berlin, whero he studied under Virchow, Trauber and Frerichs; and Würzburg, whero he qualified in 1864 with $a$ thesis on the structure of tendons and served as assistant to von Recklinghausen until 1867. Ho then went to Marburg, whero he collaborated with I,ieberkühn and Wagner in nnatomical research. In 1868 ho described the giant cells in tuberclo to which his name has been given, and it was during his stay in Marburg that he carried out some important investigations on the absorption of extravasations and the formation of pigment. In 1872 ho was appointed professor of morbid anatomy at Giessen, but in the same year succeded Klebs in the corresponding chair at I3erne, where ho did valuable work on the morbid histology of the female breast, the histology of the placenta, the distribution of glycogen in normal and diseased organs, and described tho cellular layer of the chorionic epithelium to which his namo has been given. Ho also collaborated with Kocher in a study of diseases of the tosticle. His later years wero rnainly devoted to researches on the morbid anatomy of goitro and cretinism. Ho retired from his chair two years before death, which took place on October $22,1915$.

\section{Announcements}

WE have been aslied to state that the Geological Society of I ondon is carrying on as usual at Burlington House. An announcement relating to meotings will bo mado in due course.

TuE annual oxhibition of tho Royal I'hotographic Society is being held at tho Society's House, 16 Princo's Gato, South Kensington. The exhibition is open from 10 a.m. until 5 p.m. daily (Sundays excepted) until October 7.

Mr. JoHs RYMr.L, tho arctic and antaretic explorer, has been swarded the David I,ivingstono Centenary Gold Medal of tho American Geographical Society in recognition of his leadership of the Graham Isand Expedition. Mr. Rymill, who is an Australian, wns a member of tho British Arctic Air Routo Fxpedition to Greenland in 1930-31, and took over the leadership when Mr. H. G. Watkins was lost. Ho led tho Graham Land Expedition to the Antarctic in 1934 .

Tife Council of the Institution of Nnval Architects has awarded tho Martell scholarship in naval architecture (1939) to NIr. Norman IV. H Ioney, of H.MI. Dockyard, Sheerness; the scholarship is of the valuo of $£ 130$ per annum, and will bo held at tho Royal Naval College, Greenwich. The Farl of Durham Prizo has been awarded to Mr. Peter L. Bish, of 11..I. Dockyard, Devonport.

WE have received from the British Drug Houses, Istd. (Graham Street, London, WV.l.) tho new cataloguo of B.D.H. laboratory chemicals and testing outfits, which comprises nearly six thousand separato items and is provided with $\&$ general index. Section I has been enlarged by moro than five hundred now items, mostly organic chemicals, and Section 2 con. tains an increased number of reagents and solutions for analytical and clinical purposes, and there is a now section of culture media. The products listed are normally held in stock for immediate delivery.

Dr. Albzikt B. Sabin of the Rockefeller Institute of Medical Rescarch has received the Theobald Smith award of 1,000 dollars from the American Association for the Advancernent of Science in recog. nition of his rapid method of typing in pneumonia and for a quick bedside test of a patient's probable resistance to the disease. 